\title{
PRODUCT PLACEMENT ON KOREAN DRAMA AS AN EFFECTIVE TOOL FOR BRAND POSITIONING (CASE STUDY: LANEIGE)
}

\author{
Dwi Atmi Perwitasari ${ }^{1}$, Eristia Lidia Paramita ${ }^{2}$
}

${ }^{1}$ Faculty of Economics and Business, Universitas Kristen Satya Wacana

Email:212016512@student.uksw.edu

${ }^{2}$ Faculty of Economics and Business, Universitas Kristen Satya Wacana

Email: eristia.paramita@uksw.edu

\begin{abstract}
ABSTRAK
Kemunculan Drama Korea di berbagai Negara, salah satunya Indonesia menjadi faktor meningkatnya popularitas global dan permintaan kosmetik Korea. Melalui penempatan produk dalam Drama Korea Descendants of the Sun, Laneige sebagai perusahaan kosmetik bergengsi di Korea berhasil menarik perhatian pelanggan dan menaikkan penjualan produknya. Berdasarkan fenomena tersebut, penelitian ini dilakukan untuk mengetahui efektifitas penempatan produk dalam Drama Korea bagi penempatan posisi merek Laneige di Indonesia khususnya pada area Jakarta dan Tangerang dan selanjutnya berkontribusi untuk mengidentifikasi perspektif pelanggan Indonesia tentang penempatan produk sebagai faktor kunci keberhasilan dalam hal meningkatnya keinginan pelanggan untuk membeli produk Laneige di negara ini. Data dalam penelitian ini diperoleh dengan cara membagikan kuesioner terbuka untuk memberikan kesempatan pada responden dalam memberikan pendapat diikuti dengan wawancara untuk menggali informasi secara lebih dalam. Metode yang dilakukan dalam penelitian adalah fenomenologi kualitatif dengan menggunakan teknik pengambilan sampel purposif. Sampel yang digunakan berjumlah empat informan kunci. Dalam proses analisis data, penelitian ini menggunakan metode triangulasi dan konten analisis yang kemudian membentuk proposisi dan model penelitian. Hasil dalam penelitian ini menunjukan efektifitas penempatan produk terhadap penempatan posisi merek dipengaruhi faktor kemasan produk, fungsi produk, kualitas produk, citra merek, konsep produk, kesadaran pelanggan, dan pengulangan merek. Selain itu, ditemukan faktor yang menyebabkan penempatan produk mempengaruhi keinginan pelanggan untuk membeli produk yaitu duta besar merek, kemasan produk, fungsi produk, kualitas produk dan kemunculan merek.
\end{abstract}

Kata Kunci: Penempatan Produk, Penempatan Posisi Merek, Merek, Kosmetik

\begin{abstract}
The emergence of Korean Drama in various countries, one of it is Indonesia becomes a factor in increasing global popularity and demand of Korean's cosmetics. Through product placement in the Korean Drama Descendants of the Sun, Laneige as a prestigious cosmetics company in Korea managed to attract customers' attention and increase sales of its products. Based on this phenomenon, this study was conducted to determine the effectiveness of product placement in Korean Drama for brand positioning of Laneige in Indonesia, especially in the Jakarta and Tangerang areas and subsequently contribute to identifying the perspective of Indonesian customers about product placement as a key success factor in terms of increasing customers' willingness to buy Laneige's products in this country. The data in this study obtained with distributing open questionnaires to give respondents the opportunity to provide opinions followed by interviews to dig deeper information. The method used in this research is qualitative phenomenology by using a purposive sampling technique. The sample used consisted of four key informants. In the process of data analysis, this study used triangulation method and content analysis which subsequently forms a research propositions and models. The results in this study indicate the effectiveness of product placement on brand positioning is influenced by product packaging, product function, product quality, brand image, product concepts, customer awareness, and brand repetition. In addition, this study found factors that cause product placement affect the customer's willingness to buy products which are brand ambassador, product packaging, product functions, product quality and brand appearance.
\end{abstract}

Keywords: Product Placement, Brand Positionin, Brand, Cosmetics

\section{INTRODUCTION}

Often, product placement in films is unnoticed because it blends well with the storyline and is naturally used by the actresses. In addition, there is still a gap regarding the practices of product placement literature in countries other than US (Karisik, 2014). Then, it is important for other 
countries to contribute more in product placement issues to examine the different results of literature. From the perspectives of entertainment experts such as directors, producers, media agencies and advertisers, product placement is found as a part of brand building which is a key asset for long term marketing (Kramolis \& Kopeckova, 2013) were one of key factors for brand building in competitive markets is brand positioning (Karmokar, 2014).

The effectiveness of product placement towards brand positioning strategies could be seen from several factors such as the quantity, quality, prices, or events (Edema \& Ezute, 2014). Suggested by Hanna \& Kulykovets (2016), it is important to understand the mechanism and system of product placement, also how it works from inside to measure product placement effectiveness for brand positioning. Looking at product placement from customers' perspective is a way to understand product placement mechanism and systems. Based on that, this study was conducted in Indonesia where it could reveal the impact of product placement on different groups of society for product placement studies.

Later, this study aimed to see how product placement actually affects the customer's willingness to purchase by linking the theory of product placement with the phenomenon of Laneige product placement in K-Drama, Descendants of the Sun. Several artists, either male or female, have been chosen to be Laneige brand ambassadors. From 2002 until 2006, Laneige managed to exploit the global market across Asia and claimed its brand as the "Beauty of Asia". Laneige products are available in Europe, North America also United States of America and since then, Laneige has been continuously expanding its market.

Besides using brand ambassadors, Laneige creatively does product placement in Kdrama. Through Descendants of the Sun which has a high rating and is a major hit in Asia (IMDb, 2016), Laneige places two products in the drama period, they are Laneige Two Tone Lip Bar and Laneige Whitening BB Cushion. Those products are naturally used in several scenes by Song Hye Kyo, Laneige's brand ambassador. Stated by the manager of Amore Pacific, Laneige product placement in Descendants of the Sun has been successful in Korea, China and Singapore. Since the drama was released, the number of sales has been increasing compared to the regular sales period.

The aim of this study is to examine the effectiveness of product placement in drama series for brand positioning, measure product awareness through K-drama and confirm the position of the brand. The finding of this study will contribute to identify Indonesian customers' perspective of product placement as the key success factors in terms of rising customers' willingness to buy products in this country. Research Questions: (1) What are the factors that make product placement in Korean Drama is an effective tool for brand positioning? (2) How does product placement in Korean Drama encourage customers' willingness to buy the product?

\section{RESEARCH METHOD}

This study used phenomenology method, a qualitative research method that was chosen to examine the phenomenon of product placement in the K-Drama Descendants of the Sun in customers' perspective, and hopefully it could provide a deeper understanding. The data source used in this study is primary data, which is the data obtained directly from the sources through open questionnaires and interviews that are expected to understand the meaning of respondents' answers, find factors that influence the opinion, and clarify aspects of opinion (Singer \& Couper, 2017). In addition, interview conducted to strengthen the respondents' answers and dig deeper information. 
Population of this study is viewers of K-Drama Descendants of the Sun that are interested in cosmetics. In Indonesia, the largest cosmetics users are women who have now reached 126.8 million people (Global Business Guide Indonesia, 2016) where stated by Minister of Industry (Menperin) Airlangga Hartarto millennial aged 15 to 34 years old is dominated (Kunjana, 2018). To represent the application of the results to college students and employees who are generally financially stable and can make product purchases, this study will take the middle age range in those millennials age range. Data taken was focused on Indonesia's capital city, Jakarta and involves surrounding area where Laneige's official offline store can be accessed easily by customers.

Based on that, this study was using purposive sampling technique which the requirements and characteristics of samples for this study are (1) Women that watch K-Drama Descendants of the $\mathrm{Su}$, (2) Women that know Laneige Cosmetics, (3) Women that interest in Laneige Cosmetics, (4) Women that are age between 18 to 25 years old, (5) Women that live in Jakarta and the surrounding areas. In the process of data analysis, this study used the triangulation method and content analysis to check the validity of the data. After the data is accurate and valid, it is summarized in the forms of the table to create propositions and models.

Table 1

Operationalization of Variables

\begin{tabular}{|c|c|c|c|}
\hline Variable & Operational Definition & Indicator & Source \\
\hline \multirow[t]{3}{*}{$\begin{array}{c}\text { Product } \\
\text { Placement }\end{array}$} & \multirow{3}{*}{$\begin{array}{l}\text { Placing products in a } \\
\text { communication media } \\
\text { such as films, theater } \\
\text { performance, television } \\
\text { program to reach } \\
\text { customers awareness, } \\
\text { advance rensumer } \\
\text { recognition, and further } \\
\text { affects ransumer } \\
\text { preference r and } \\
\text { purchase intention } \\
\text { (Hanna \& Kulykovets, } \\
2016 ; \\
2016) .\end{array}$} & $\begin{array}{l}\text { - Product placement can draw viewers' attention by its } \\
\text { physical information. } \\
\text { - Product placement can show product functions. } \\
\text { - Product placement can show how the product is used. } \\
\text { - Product placement can increase the curiosity of viewers. } \\
\text { - Product placement can increase the customers' } \\
\text { willingness to buy product. }\end{array}$ & Srivastava, (2016) \\
\hline & & $\begin{array}{l}\text { - Product placement can convey the hidden message of the } \\
\text { product. } \\
\text { - Product placement message is integrated with the } \\
\text { content. }\end{array}$ & Karisik, (2014) \\
\hline & & $\begin{array}{l}\text { - Product placement could reach unlimited range of } \\
\text { customers. }\end{array}$ & $\begin{array}{l}\text { Hanna \& Kulykovets, } \\
(2016)\end{array}$ \\
\hline \multirow[t]{5}{*}{$\begin{array}{c}\text { Brand } \\
\text { Positioning }\end{array}$} & \multirow{5}{*}{$\begin{array}{l}\text { Brand positioning is the } \\
\text { process of creating } \\
\text { sustainable trademark } \\
\text { image to measure } \\
\text { customers' engagement } \\
\text { with the trademarks } \\
\text { itself (Fayvishenko, } \\
\text { 2018). }\end{array}$} & - Brand positioning can attract customers. & $\begin{array}{l}\text { Fayvishenko, (2018); } \\
\text { Edema \& Ezute, (2014) }\end{array}$ \\
\hline & & $\begin{array}{l}\text { - Brand positioning can place the brand in customers' } \\
\text { mind. }\end{array}$ & Sapatnekar, (2015) \\
\hline & & $\begin{array}{l}\text { - Brand positioning can create value for customers. } \\
\text { - Brand positioning can differentiate product from } \\
\text { competitors. }\end{array}$ & Kotler \& Keller, (2012) \\
\hline & & - Brand positioning meets customers' expectations. & Gelder, (2013) \\
\hline & & - Brand positioning is used to target specific market. & Edema, (2012) \\
\hline
\end{tabular}

\section{RESULT AND DISCUSSION}

\section{Characteristics of respondents}

This study conducted on November $1^{\text {st }}, 2019$ to find information about product placement on Laneige's product in Jakarta and Tangerang. On January 5th, 2020, this study managed to get the necessary data from four respondents that identified as key informants where meets the requirements of data collection. Key informant comes from an age range that is not much different which is 20-22 years old who lived in Jakarta and Tangerang. Key informants interested in Laneige Cosmetics and have watched Korean Drama Descendants of the Sun. However, the 
difference in the amount of watching Korean Drama Descendants of the Sun further allegedly as a factor that makes key informant have a different statement about product placement and brand positioning.

\section{Factors that make product placement an effective tool for brand positioning.}

After collecting data from key informants based on fourteen indicators to answer the first research question, there are seven factors that identified as factors that could be used to measure product placement effectiveness for brand positioning.

\section{Product packaging}

When the product appears, attractive packaging can evoke the focus of the audience who can directly record Laneige products in customers' memory (Edema, 2012). Product packaging seen from study result by Edema, 2012 is one of brand positioning strategies based on size, color and graphics where customers are usually attracted by the visual of product such as the letters or alphabet, colors, design and styles. This is supported by the statement of all key informants that can explain in details the characteristics of Laneige packaging that is simple and luxurious dominated by blue. Specifically, a key informant aged 21 years old describes her opinion as follows,

Key Informant A: "Laneige blue color is interesting because the solid color selection alone can make the product looks expensive and it can show calmness and maturity."

This statement is strengthened by key informant B's statement who feels that Laneige's packaging looks elegant and luxurious. Even when one of the key informants finds another product that has same qualities as Laneige, she prefers to buy Laneige only because its packaging is better, so it means the packaging totally boosts the product qualities. That statement in the practice is completed by statement of key informant $\mathrm{C}$ that lived in Jakarta who believes that the product packaging from Laneige managed to represent a good product. She personally liked this packaging and wants to have it just because interested by its packaging. It can be seen that brand positioning Laneige successfully delivered to customers through a product placement in particular product packaging that is identified have a big impact on customers' perception of Laneige brand position.

\section{Product function}

Through the product function that showed by product placement in Korean Drama Descendants of the Sun, key informants could see several things such as method of using the products, the effects that product gives, and the qualities of the product. This is the reason why product functions being an important factor that need to be consider for creating an effective product placement for brand positioning. According to the past studies by Edema, 2012 product quality can be measured in brand positioning strategy by the core and aesthetic functions. All key informants have same statement about Laneige's product function that is simply function as a makeup where it is actually the core function of Laneige products. Based on key informant D's statement, the aesthetics function of the product is to make face looks prettier. In this study, the simple function of Laneige's products as makeup then questioned more about its easiness to use and is the product practical to carry everywhere where further it can prove that demonstrates the product function properly can create value in the key informants' mind. These values that created in key informants' mind found out to be positive value that could help Laneige positioning their brand as a brand that produce good product where practical to used and bring everywhere. 


\section{Product qualities}

There is outward strategy to positioning brand by its qualities that focused on customers' emotion by product psychical and psychological appearance to bring positive experience of using the brand (Edema, 2012). Through it psychical appearances which is packaging, Laneige make customers experience feeling that the product have a good qualities just what key informant B stated that it is further lifts her personal preferences to choose Laneige. Product function is part of psychological appearances that showed by Laneige through product placement in Korean Drama Descendants of the Sun where customers' emotion shapes to bring positive experience of using the brand. Just by looking at the demonstration of product use in the scene, key informants could explain products' qualities.

Key informant A: "Ten out of ten I am willing to buy the product because it is worth it. It has good qualities and good effects by looking at how Song Hye Kyo applied the products."

Key informant C: "The lipstick gives pretty final look and it makes Song Hye Kyo look better also ready to date. Seven out of ten, I am willing to buy the product because the qualities that is good"

Those statements showed that key informants are sure about the qualities of the products and the benefit of using Laneige's products. By showing product qualities, product placement could be more effective to apply for get brand positioning in customers' mind.

\section{Brand image}

This process specifically talks about creating special image, special property, positive associations and values in customers' minds. Based on that, product placement can be seen as effective if it covers brand positioning purposes to create brand image in customers' mind. Laneige develop the brand image by popularity through their brand ambassador, Song Hye Kyo (Guambo, College, \& Fetsecherin, 2016). Laneige believes in natural beauty that everyone has as a sparkling charm where it makes everyone shines whenever and wherever with confidence. "Let your charm sparkle!" is represented with elegant, simple and luxurious products that makes Laneige focused on middle up customers by set high-end prices and select high class brand ambassador.

Key informant D: "Laneige shows luxury in the brand image by simple and minimalist way through the product concept, packaging and their brand ambassador. I could really see that Laneige is a trusted product by looking at the image"

Key informant D's statement has showed Laneige's brand image that catched by watching several scence in Korean Drama Descendants of the Sun. The purposes of brand positioning strategies are to create value and differentiate brand from competitors (Edema, 2012). In this case, brand image help customers differentiate Laneige's products with other similar products such as The Body Shop, Inisfree, Clio, Etude House and etc.

\section{Product concept}

Laneige innovation on its products is flexible by following trends and women needs in beauty. Through innovative products, Laneige managed to lead the beauty trend in line with trendy sensibility and lifestyle of young women around the world until become a favorite brand of Asian women by entering the global market. Laneige have been applied the innovation in Laneige Two-Tone Lip Bar product concept by put two color in one lipstick to create ombre look that is trend in this era. Laneige made an effective and efficient product concept on the lipstick where anyone could get the best look by used only one product in short time.

Key informant C: "I like the concept of Laneige lipstick. It is practical and easy to use. Just by one swatch you will get nice ombre look while usually it takes two lipstick products. The lipstick's shape is just perfect. It is titled and slim so it is easy to apply in your lips." 
In product concept strategy, Laneige likes to use viral marketing that is in line with Laneige innovations that always follow the trend of young women's lifestyle. Korean Drama Descendants of the Sun successfully made "Laneige Two-Tone Lip Bar" have the highest point of sales in 2016 because it is trendy and popular as "Song Hye Kyo lipstick". Strengthening Laneige's popularity statement through its product concept, one of the key informants put Laneige in her mind as a must have item on the year of the Korean Drama Descendants of the Sun being released in Indonesia.

Key informant B: "The second time of watching Descendants of the Sun, I was getting more interested with the product and the brand because it is so hype at that time. It feels like Laneige is a must have item. Everyone has it and it becomes popular."

In fact, it is not the first time for Laneige to make their product concept "viral" to get higher number of sales. Found by Guambo et al., 2016 Laneige started to establish "trend-setting makeup" in 1996 through Live Like a Movie Campaign to trademark certain trend such as Hepburn Bronze and Sexy no.1 look. New Millennium product concept that used advance science on creating sophisticated beauty of modern women in 2000 also became a trend in the launching of "Everyday New Face" campaign. From here, it is clear that in reality product concept has made a long way before the product launching and selling on the market have a big effect on the product placement's effectiveness for brand positioning.

\section{Customers awareness}

Product placement is known as non-traditional method and attractive path to reach customers awareness, advance consumer recognition, and further affects consumer preference and purchase intention which, in practice, the customers are often unaware of the commercial persuasion effort (Srivastava, 2016). When product placement was in line with the story and has an interaction with the actress, customers unconsciously will aware of product value showed in the appearance (Karisik, 2014). All key informants have captured some hidden messages that Laneige wanted to show such as the products quality that is good, the product is pigmented, the products makes you look prettier and etc. It supported the statement by Karisik, 2014 that hidden messages can be delivered to customers through product placement although customers do not have any expectations in products that showed up in Korean Drama Descendants of the Sun.

Next, the key informants managed to see the position of the Laneige brand and who was their target and segment in marketing. Especially, customers can identify Laneige segmentation based on the demographic where it includes variables such as age, gender, social class etc. (Kotler \& Keller, 2012). From customers' recognition about Laneige segment, it wills helps Laneige become more focused on the target and later will bring positive and strong positioning. The level of customer awareness is seen as the key to successful product placement for brand positioning, because if customers are not aware at all at the appearance of the products, then the efforts made by the brand is considered as totally fail.

\section{Brand repetitions}

The frequencies of each key informant watching Korean Drama Descendants of the Sun is diverse, and it turns out determining how many key informants can capture the value of a brand, place it in their minds and ultimately help raise purchase intention. Key informant A and B who watched the Korean Drama Descendants of the Sun thrice can tell more stories about Laneige's products, they can even mention the exact episode this product appeared (episode 1 and episode 9) and started to understand that it is actually part of sponsorship and advertisement. But, that 
awareness did not make key informant then issue negative opinions to the product placement. Instead, key informant A became a loyal customer of Laneige until now.

When key informant D who watched Korean Drama Descendants of the Sun twice wanted to buy Laneige's products, she would remember the appearance of the brand in the Korean Drama Descendants of the Sun. Key informant C, although only watches Korean Drama Descendants of the Sun once can also be actively involved in telling the brand values or brand position in his mind. The higher level of brand repetition can be achieved if the Korean Drama is good, interesting to watch for several times, has a high rating for long period of time and can be broadcasted worldwide. This is why considering brand repetition when doing product placement is important for brand positioning.

\section{Product placement in Korean Drama encourages customers' willingness to buy the product.}

There are six indicators to measure how product placement can increase the customers' willingness to buy product that is related with the used of product placement as an effective tool for brand positioning comes up from past studies by Edema, (2012) and Srivastava, (2016) Edema (2012). Prices, physical information such as size, color, and graphics which is part of packaging, qualities, function, personalities/celebrities and the appearance of brand itself are highlighted as factor that used to attract customers. From those indicators, there are five factors comes up as factors that could be used to measure customers' willingness to buy product after seen product placement on Korean Drama which are brand ambassador, product function, product packaging, product qualities and brand appearances.

Brand ambassador played significant roles on increasing customers' willingness to buy product from product placement scene. The ratio between the key informants who agree and disagree with the statement "an artist who uses the brand encourages customers' willingness to buy the product" is 3: 1 where this number represents there are more people interested in buying the product. Laneige chooses Song Hye Kyo as their brand ambassador because Laneige believes Song Hye Kyo has the power to influence many people through the natural beauty typical of authentic Korean women. Three out of four key informants agreed that Laneige's brand ambassador has encouraged their willingness to buy the product. They believe that Laneige has chosen the perfect ambassador for their brand because their opinion about Laneige comes up in a positive way because of Song Hye Kyo.

Key Informant C: "Song Hye Kyo fits Laneige brand image very well. She makes Laneige looks luxurious and pretty. She fits the brand. She has been Laneige brand ambassador for a long time. I believe that during that period, she must use the product and it just shows that the product is good."

Key Informant $D$ : "She is beautiful and elegant at the same time. She makes me think that the product is good."

Song Hye Kyo as Laneige brand ambassador that is also the main character in Korean Drama Descendants of the Sun successfully influences the key informants to buy the product. Those statement proved the studies by Hanna \& Kulykovets, 2016 about customers that get more attracted with a certain product because of the brand ambassador who become customers' object of desire. By choosing the brand ambassador that is interested as a character in Korean Drama and fit the brand and product value's well, customers' willingness to buy products will increase. Next, determine the appearance of the product scene that is integrated with the storyline of Korean Drama through the brand ambassador so it can bring up product functions, product packaging and product quality through its usage will also increasing customers' willingness to buy products. 
Product function that appears in the Korean Drama Descendants of the Sun is simply as makeup that boosts your beauty but all key informants agreed that the function is good and they are willing to buy the product because of the function. From the function shown, the key informants know that this product can be used easily and the results given are different from other makeup products. Product functions that are simply described as factors that influence the success of product placement for brand positioning then further show the quality of the product. Through these functions, the key informants can also find out how to use the product. This is strengthening the past studies by Hanna \& Kulykovets, 2016 that stated product function is very significant in product placement. It enables product recognition so in the end customers could differentiate it from other brands.

In this study key informant A stated that product packaging is certainly seen as an important factor influencing customers' willingness to buy products that placed in Korean Drama. This is supported by the statements of the other three informants, key informants B, C, and D who said that they wanted to buy Laneige products because they were influenced by the product packaging.

Key Informant A: "Most women buy products based on product packaging, whether the packaging is attractive enough to be bought and showed through social media, and etc. In fact, it is not uncommon for women to buy products just because the packaging is good or cute."

Measuring the products that have been selected, whether the physical appearance of the product already represents the main product information and value such as the logo, name, color, and shape can increase customers' trust so that they are compelled to make a purchase (Hanna \& Kulykovets, 2016). Laneige's simple, elegant and luxurious packaging makes the trust of all key informants to Laneige products increase. Their willingness level rises when they see the packaging clearly depicted because the right shoots that taking leads to Two Tone Lip Bar and Whitening BB Cushion. The shooting was successfully integrated with the story line so that key informants were affected indirectly on the product.

Furthermore, product qualities are certainly an important factor to attract customers' attention because it can bring many benefits. Product with a good quality will surely create a good company reputation, increase sales, and even expand the market. In less than five minutes period of time Song Hye Kyo used Two Tone Lip Bar and Laneige Whitening Cushion which at first glance, it only shows the way the product is used and how the product functions while the product qualities come from Song Hye Kyo's final look when she has finished using the product. And this quality makes the key informants want to buy products. Showing the quality of the product in the product placement really helps increase customers' willingness to buy the products because in essence the buyer wants the best results when buying a product. Another factor is seen as a complementary or supporting factor to determine the success of the brand to influence customers to buy it.

Other important thing to do in product placement so it could increase customers' willingness to buy products is perform screen tests to ensure the appearance of the product looks natural and can creates curiousity from the eyes of viewers or customers. Brand appearance is a tool to achieve competitive advantage that can reflect the essence of business which is product marketing in forms of selling to get profit (Hanna \& Kulykovets, 2016). The appearance of Laneige brand in the Korean Drama Descendant of the Sun succeeded in making all key informants remember the Laneige brand logo, name, also the white and blue colors that appeared. Three of four key informants stated that the emergence of this brand had an influence on their desire to buy Laneige products. Brand appearance helps customers identify the 
product. The appearance of the brand will determine how much customers are curious about the product then find out and finally want to buy also make a purchase. The appearance of the product also has a pretty good impact on the sale of other Laneige products because there has been a good image that is successfully raised through this Korean Drama Descendants of the Sun. As stated by key informants A and $\mathrm{C}$ that when they wants to buy Laneige products or just see Laneige store in a mall or even just Laneige advertisements on online sites, they could recall the appearance of the Laneige brand in the Korean Drama Descendants of The Sun.

The model below showed in Figure 1 and 2 explains the relation of each variable for the effectiveness of product placement for brand positioning and how product placement encourage customers' willingness to buy product.

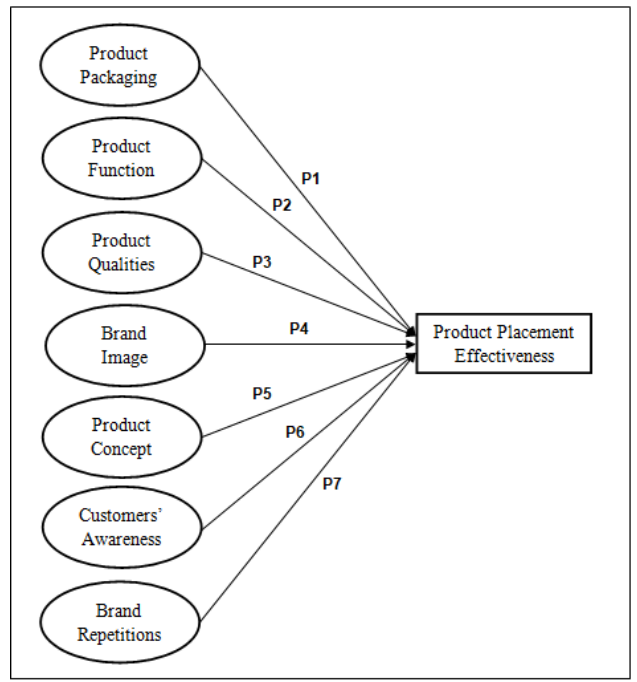

Figure 1

Factors that make Product Placement an Effective Tool for Brand Positioning Source: Primary Data, 2019

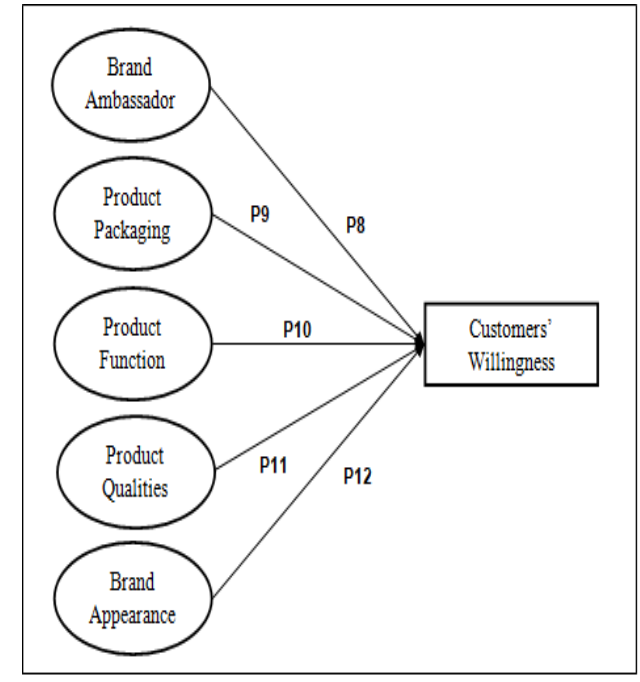

Figure 2

Factors that make Product Placement Increase Customers' Willingness to Buy Products Source: Primary Data, 2019

\section{CONCLUSION AND RECOMMENDATION}

Variables that appear as factors that make product placement an effective tool for brand positioning are product packaging, product function, product qualities, brand image, product concept, customers' awareness and brand repetitions. The effectiveness of product placement for brand positioning can be assessed as maximum when product placement can cover almost all indicators that measure successes of brand positioning in the same time. In this case product placement in Korean Drama succeeded in attracting the attention of customers through product physical appearance including Laneige's simple, elegant and luxurious packaging which then brought the customers to see the product's function maximally through its simple practice on how to use it. After that, customers can give a positive assessment of product qualities and brand image through its unique product concept shown. Product placement also successfully shows the value of the product through the hidden messages that are, consciously or not, received by the customers because this message is integrated with Korean Drama content.

Variable that appears as factors that make product placement encourage customers' willingness to buy product are brand ambassador, product function, product packaging, product qualities and brand appearance. Products appearances brought by the artist in Korean Drama Descendants of 
the Sun make customers willing to buy Laneige products. This is supported by the success of the artist in showing a good image on the product through her beauty and elegance that ultimately can represent Laneige perfectly. The artist also successfully demonstrated the function and quality of the product when applying it simply so that the natural final result was assessed as an excellence in Laneige product quality. Laneige's packaging and brand logo that is simple, elegant and luxurious are also the additional reasons that increased customers' willingness to buy these products and ultimately lead to cross selling other Laneige products.

\section{Limitation and Suggestion}

This study is limited in two areas which are Jakarta and Tangerang thus it does not cover other Laneige distribution areas such as Surabaya, Semarang and other big cities that is why future studies need to take broader data for make a better representation on the role of product placement and brand positioning in Korean Drama especially in Indonesia. This study does not emphasize the authenticity and source of product purchases by customers because this study only want to see the effect of product placement in Korean Drama for the brand positioning of Laneige. Whereas, there are many similar products in the markets, even the similarity is almost indistinguishable because of the very easy access to buying and selling at this time. It is important for future studies to identify the authenticity of the products used by key informants by including the source of the product purchase in the criteria of the key informants. It will helps future studies to get more accurate data for the company.

This study has succeeded in finding two models to prove the relationship between product placement on Korean Drama and brand positioning also the product placement relationship to customers' willingness to buy the product but have not been able to measure the level of each factor found in the model. Future studies can use the models that have been found to measure the contribution level of each factor in quantitative research so that it can be determined which factors should get more attention in the product placement process and which are supporting and complementary factors.

\section{Acknowledges}

Praise and thanks to Jesus Christ for the infinite of blessings, gifts and love in every process of writing this publication. With boundless love and appreciation, author would like to extend her heartfelt gratitude to key informants $\mathrm{A}, \mathrm{B}, \mathrm{C}$, and D who have been to be respondents of this study.

\section{REFERENCES}

Edema, A. J. M. (2012). Public Relations: Tools and Techniques in Marketing Communications. Public Relations Journal, 8(1), 11-15.

Edema, Alfred J M, \& Ezute, I. F. (2014). Branding and Brand Positioning: A Conceptual Conflict Perspective in Product and Corporate Strategies. Scientific Research Journal (SCIRJ), 2(1), 49-54.

Fayvishenko, D. (2018). Formation of Brand Positioning Strategy. Baltic Journal of Economic Studies, 4(2), 245-248. https://doi.org/10.30525/2256-0742/2018-4-2-245-248

Gelder, P. Van. (2013). A Framework for Brand Positioning Strategies.

Global Business Guide Indonesia. (2016). Overview of Indonesian Cosmetic Sector: Growing Domestic and Export Markets. Retrieved from http://www.gbgindonesia.com/en/manufacturing/article/2016/overview_of_indonesian_cos metic_sector_growing_domestic_and_export_markets_11593.php

Guambo, L., College, R., \& Fetsecherin, M. (2016). Laneige: International Marketing Plan. 
Hanna, G.-W., \& Kulykovets, O. (2016). Positioning Product Placement as an Effective Tool for the Brand Positioning Hanna. Intech, I(1), 1-13. https://doi.org/http://dx.doi.org/10.5772/57353

IMDb. (2016). Popularity Ascending "Descendants of the Sun", Released between 2016-01-01 and 2016-12-31. Retrieved May 5, 2019, from https://www.imdb.com/search/title?release_date=2016\&title=Descendants+of+the+Sun

Karisik, V. J. (2014). 20 Years of Research on Product Placement in Movie, Television and Video Game Media. Journal of Economic and Social Studies, 4(2), 253-283. https://doi.org/10.14706/JECOSS

Karmokar, P. P. (2014). All about Brands and Brand Building. International Journal of Innovation and Scientific Research, 3(1), 54-61. Retrieved from http://www.ijisr.issrjournals.org/

Kotler, P., \& Keller, K. L. (2012). Framework for marketing management. Pearson Education.

Kramolis, J., \& Kopeckova, M. (2013). Product Placement: A Smart Marketing Tool Shifting a Company to the Next Competitive Level. Journal of Competitiveness, 5(4), 98-114. https://doi.org/10.7441/joc.2013.04.06

Kunjana, G. (2018, March 20). Industri Kosmetik Nasional Tumbuh 20\%. Daily Investor Indonesia. Retrieved from https://investor.id/industry-trade/industri-kosmetik-nasionaltumbuh-20

Sapatnekar, N. (2015). Brand Positioning: Control or Influence on Buying Patterns of Customers. IJAPRR International Peer Reviewed Refereed Journal, II(Vii), 12-17.

Singer, E., \& Couper, M. P. (2017). Some Methodological Uses of Responses to Open Questions and Other Verbatim Comments in Quantitative Surveys. Methoden, Daten, Analysen, 11(02), 115-135. https://doi.org/10.12758/mda.2017.01

Srivastava, R. K. (2016). Promoting Brands through Product Placement in Successful and Unsuccessful Films in Emerging Markets. Journal of Promotion Management, 22(3), 281300. https://doi.org/10.1080/10496491.2015.1095831 